\title{
The Research of Factors Affecting the Effectiveness of Internal Control Systems in Commercial Banks-empirical Evidence in Viet Nam
}

\author{
Ho Tuan $\mathrm{Vu}$ \\ Correspondence : Ho Tuan Vu, Duy Tan University, 182 Nguyen Van Linh street, Thac Gian ward, Dist Thanh Khe, \\ Da Nang City, Vietnam. E-mail: hotuanvu@dtu.edu.vn or hotuanvu2007@yahoo.com
}

Received: April 5, 2016

doi:10.5539/ibr.v9n7p144

\author{
Accepted: May 5, 2016 \\ Online Published: June 14, 2016 \\ URL: http://dx.doi.org/10.5539/ibr.v9n7p144
}

\begin{abstract}
The purpose of this research was to determine the factors that affect effectiveness of internal control systems in commercial banks in Vietnam. Through the method of qualitative research and quantitative based on reliability Cronbach's Alpha, exploratory factor analysis (EFA) and multiple regression analysis (MRA). According to the report of COSO, BASEL organizations and the other authors, control environment; risk assessment; information and communication; control activities and monitoring could affected the effectiveness of internal control systems in commercial banks. In addition, this research has indicated that there are two new factors have an impact on the effectiveness of internal control systems in commercial banks in Vietnam: political institutions and interest groups.
\end{abstract}

Keywords: factors, effectiveness of internal control systems, commercial banks, Vietnam

\section{Introduction}

There were many researches on internal control system, the effectiveness of internal control system as well as factors affecting the effectiveness of internal control system. Some researches on internal control system and the effectiveness of internal control system were COSO (1992), Coco (1994), Basel (1998), Turbull (1999), Ge, W., \& McVay, S. (2005), O'Donnell (2005), Doyle et al.(2007), Angella Amudo \& Eno L. Inanga (2009), Sultana \& Haque (2011), etc. Besides, some researches on factors affecting the effectiveness of internal control system were Ramos (2004), Rae \& Subramaniam (2006), Lannoye (1999), Walker (1999), Steihoff (2001), Hevesi ( 2005), Jenkinson (2008), Springer (2004), Muhota (2005), Diamond (1984), Calomiris \& Kahn (1991).

However, there had not been any research on factors affecting the effectiveness of internal control system in commercial banks in Vietnam. Therefore, this study will focus on the effectiveness of internal control system as well as factors affecting them in commercial banks in Vietnam.

\section{Literature Review}

\subsection{The Effectiveness of Internal Control Systems}

The report of the COSO (1992), Basel (1998), COSO (2013) said that: an internal control system is effective if the Board of Directors and the managers achieve the following criteria:

- They understand clearly the objectives of their organization

- The financial statements are prepared and presented reliably

- The laws and the regulations are being complied.

Beside those criteria, five other components of the internal control systems should be evaluated to consider the effectiveness of internal control system.

\subsection{The Factors that Affect the Effectiveness of Internal Control Systems}

\subsubsection{Control Environment}

Control environment is one of the key components of an entity's internal control, it sets the tone of an entity, influences the control consciousness of all people within the organization and is the foundation for all other components of internal control system (Ramos, 2004). Some of the components of control environment for this study are; corporate culture, Competence levels, Quality of audit committees and Integrity and ethics (D'Aquila, 1998 \& Ramos, 2004). According to Rae \& Subramaniam (2006), the core of any organization is its people and they are the engine that drives the organisation. They further assert that individual attributes (integrity, ethical values and 
competence) and the environment in which they operate determine the success of the institution and that the control environment as established by the organization's administration sets the tone of an institution and influences the control consciousness of its people. Control environment factors as listed by Subramaniam et al., (2006), include:

- Integrity and ethical values;

- The competence of an institution's people;

- Leadership philosophy and operating style;

- The way management assigns authority and responsibility and organizes and develops its people.

In relation to Subramaniam et al, (2006) organisational values cannot rise above the integrity and ethics of the people who create, administer and monitor them.

\subsubsection{Risk Assessment}

Lannoye (1999) said that the approach can vary between businesses but they must be designed to maintain an appropriate risk management through consideration of the concept of reasonable assurance about the cost-benefit balance. According to Walker (1999), the management of risks in the process of change should be designed to prevent or minimize the risk, managers should monitor any changes to ensure that each risk management continued when a change occurs. Managers should inform responsible employees directly about any proposed change in risk management. Managers should continue to monitor the factors that can affect the risk can create new risks.

According to the Lannoye (1999), this component of internal control system highlighting the importance of identifying caution in management and reviews the factors that can make your business barriers to achieve its mission. Risk assessment is a systematic process of integration of the adverse conditions and events can occur, evaluate the damage can (financial and non-financial). Precondition to risk assessment is business must have clear objectives, as appropriate. Internal control give businesses the way in risk assessment from the inside as well as outside business like: identify risks; Risk analysis; Estimating the risk; Reviews of frequency of occurrence; Consider how to manage the risk

\subsubsection{Control Activities}

According to Jenkinson (2008), control policies and procedures must be established and executed to help ensure that actions necessary to achieve the institution's objectives are effectively carried out. It is further argued that control activities are the policies and procedures that help ensure that management directives are carried out and also controlled activities occur as diverse as approvals, authorizations, verifications, reconciliations, reviews of operating performance, security of assets and segregation of duties. Similarly reviews should be made of actual performance versus budgets, forecasts and performance in prior periods and performance reviews should be made of specific functions or activities. Reviews in banks may focus on compliance, financial or operational issues. Ramos (2004) suggests that a variety of control activities should be performed to check the accuracy and completeness of information as well as the authorization of transactions. Development of new systems and changes to existing ones should be controlled. Additionally, access to programs and data should be restricted. Physical controls include control of equipments, inventories, securities, cash and other assets which should be secured physically and periodically counted and compared with amounts shown on control records. Performance indicators may be through anticipating certain operating results by investigating unexpected results that jeopardize the achievement of the banks' objectives. Duties are segregated among different people to reduce the risk of error or inappropriate actions. For example, responsibilities for authorizing transactions, recording them and handling the related assets should be separated.

\subsubsection{Information and Communication}

Communication systems represent the institution's channels and methods of conveying important information, policies and directives as cited by Robert \& Abbie (2003). In relation to the above, surrounding control environment activities are information and communication systems that enable the organization's people to capture and exchange the information needed to conduct, manage and control its operations therefore pertinent information must be identified, captured and communicated to appropriate personnel on a timely basis, thus effective communication must flow down, across and up the organization.

The study of Steihoff (2001) and Hevesi (2005), have shown that information and communication is an important factor affecting the effectiveness of the Internal Control systems. Information must be determined reliably from both inside and outside the enterprise, to be informed and handled by people with functions in a timely manner. Media information to be communicated officially and allowed by the board and staff to perform its responsibilities. Information and communication system that allows all employees understand their role in the control system, and the people involved. Businesses must be able to prepare accurate and timely financial reporting, including interim reports to report to managers to perform full responsibility and decision-making in a timely manner. Therefore, the need for job 
descriptions for all levels in the enterprise.

\subsubsection{Monitoring}

Monitoring is one of the most important aspects of internal control in any organization. According to Springer (2004), monitoring the performance of the internal control system over time, made continuous or separate assessment. The purpose of the monitoring is to determine the internal control made properly, fully and efficiently as designed all five components.

Monitoring is an ongoing activity which involves performing procedures periodically and reviewing banks documentation to confirm that all procedures have been performed as required (Muhota, 2005). The tools used in many organizations are reconciliations, internal checks and audits to ensure the accuracy of transactions being reported in financial statements in monitoring loans (Diamond, 1984). The entire process must be monitored and modified as necessary, thus the system can react dynamically to changing conditions. Internal control systems need to be monitored, a process that assesses the quality of the system's performance over time. This is accomplished through ongoing monitoring activities, separate evaluations or a combination of the two. Ongoing monitoring occurs in the course of operations. It includes regular management and supervisory activities and other actions personnel take in performing during their duties. A good monitoring system should be able to identify internal control deficiencies and be reported immediately to top administration and governing boards as stated by Calomiris \& Khan (1991).

\subsubsection{Political Institutions}

Zingales's (1998), Beck (2003) points out that the political institutions that affect development finance. Kaufmann \& partner (2009) has built the norms reflect the political institutions of a country, including: the quality article, political stability, government effectiveness, accountability, corruption control policy. Group author using the indicators were calculated, published and updated annually by the World Bank (World Bank database) to reflect the political factor. Kenjegalieva \& Simper (2011) find that next to the macro economic factors, corruption in the organs of public power and the low efficiency of the Executive apparatus of the negative influence to results of operations of the Bank.

\subsubsection{Group Interests}

Rawls, J.A. (1971) starting a political institutions are considered civilized when there is perfect legal system, create that important among interest groups, actively develop the mechanism of resistance through the reform process, constant innovation, regular, long, constantly backlogged, and separation of powers for the various components of the apparatus the right to monitor and the balance of power. Frank Scarpatti (1977) for that to continue building, modernization of the control mechanism of State power, the creation of a mechanism capable of encouraging the maximum positive influence of interest groups as well as minimize the negative influence of interest groups. Allan J. Cigler \& Burdett A. Loomis (1995) states that benefits from the group forming the interest group. The society is a complex benefit system along with the interaction of interests in each group, or between different groups in a State competition, struggle continually to hold equal ownership, the distribution of public resources and the right to participate in the process of shaping, through, establishing the decision policy, in terms of State power with the purpose of bringing the benefits of the highest group. No formation, existence the Group stood outside interests. The society, which is a synthesis of the various interest groups, the number of them being regulated and limited by a single index: benefits-from which they link, form and operation.

From the model of the factors that influence the effectiveness of the internal control system of the authors before, when performing in-depth interviews with experts in the field of audit, the Bank in the country, the author proposes a research model to match the current conditions of the Vietnam commercial bank are as follows: 


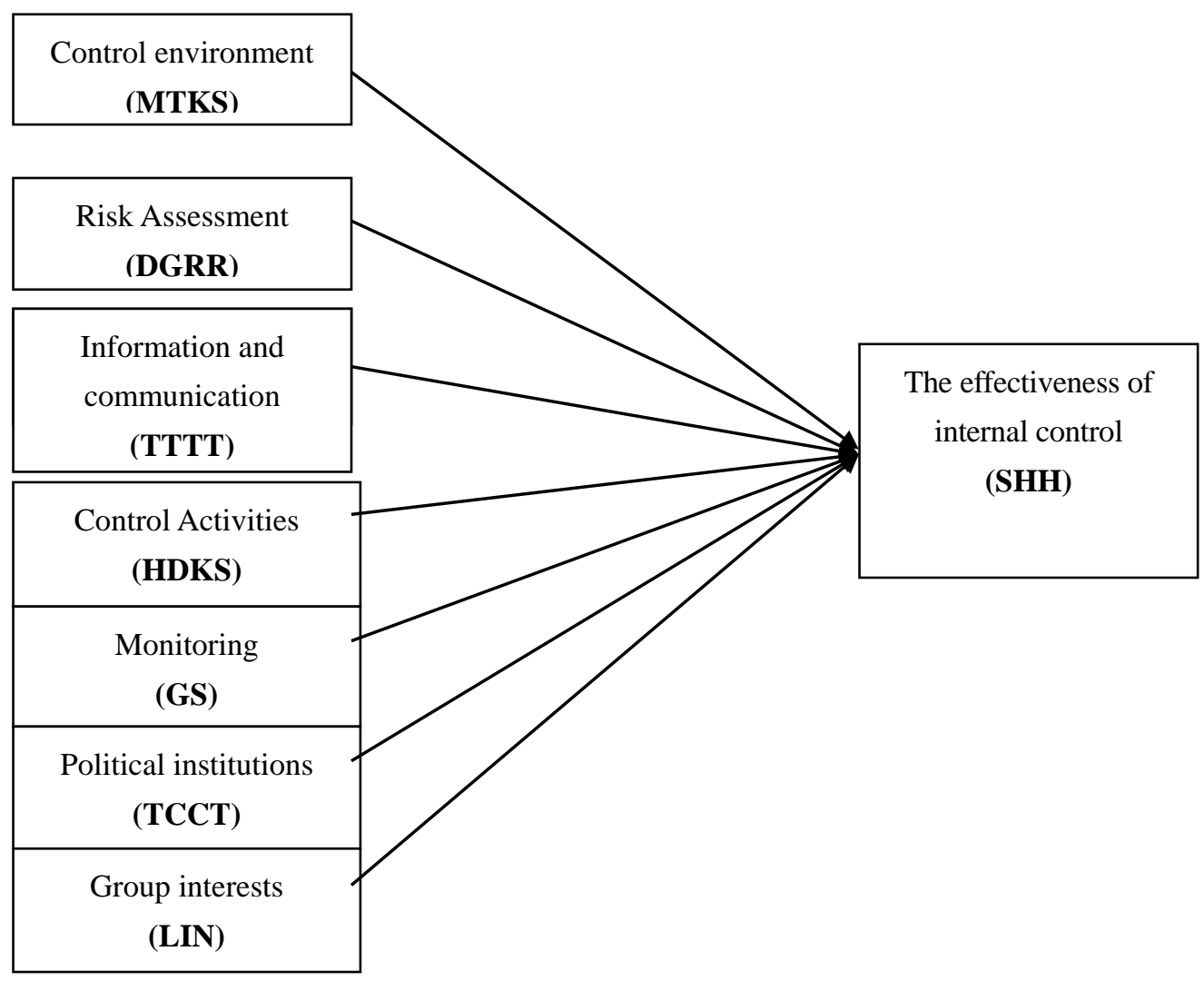

Figure 1. Proposed model of factors affecting the effectiveness of internal control system in comercial bank of Viet Nam. (Source: The model proposed by author)

Thus, the hypotheses are posited as follows.

Hypothesis 1: The greater the control environment is, the more likely that intenal control systems will achieve more effectiveness.

Hypothesis 2: The greater the risk assessment is, the more likely that intenal control systems will achieve more e effectiveness.

Hypothesis 3: The greater the control activities are, the more likely that intenal control systems will achieve more effectiveness.

Hypothesis 4: The greater the information and communications are, the more likely that intenal control systems will achieve more effectiveness.

Hypothesis 5: The greater the monitoring is, the more likely that intenal control systems will achieve more effectiveness.

Hypothesis 6: The greater the political institutions are, the more likely that intenal control systems will achieve more effectiveness.

Hypothesis 7: The greater the Group interests are, the more likely that intenal control systems will achieve less effectiveness.

\section{Data Collection and Research Methodology}

The data were collected from the survey in 37 commercial banks in the $4^{\text {th }}$ quarter of 2015 in Vietnam. There were 600 managers (in the total of 1,000 managers at commercial banks Vietnam) participated in this survey. After eliminating the invalid votes, 512 remaining votes were reliable to analyze. To achieve the goals of this research, I used a combination of the qualitative and quantitative methods.

Qualitative research was applied by interviewing the experts. Based on the collecting opinions from experts (including the Ministry of Finance, the State Bank of Vietnam, Vietnam Banking Association) about the factors affecting the effectiveness of internal control system, I developed, adjusted and rearranged the questionnaire to set a formal scale to do the servey in commercial banks in Vietnam.

Quantitative method was used by these steps: designing the study, collecting data, quantitative analysis using software 
version 20.0 SPSS. This software is used to synthesize and present basic data about the frequency of variables and statistical description of factors and their impact on the effectiveness of internal control systems. In this study, first author using Cronbach Alpha Test techniques to test the factors of the scale then use technical analysis exploratory factor (EFA) to reduce the observed variables, change variable names and models shortened; finally ran regression models through regression analysis techniques to assess the final conclusions of the factors that affect the effectiveness of internal control in comercial bank of Viet Nam.

\section{Result and Discussion}

In this survey, the authors propose a model of 35 variables independent observers (variables) gathered in 7 groups of factors (Factors) and 3 observers for the dependent variable. To test the reliability of the scale model of the original author used the Cronbach's Alpha testing. Results of the testing were eliminated from model 8 observations following:

Table 1. Testing the rating scale by Cronbach's Alpha reliability coefficient (reliability statistics item-total statistics). Source: The results of analysis from SPSS 20.0 software

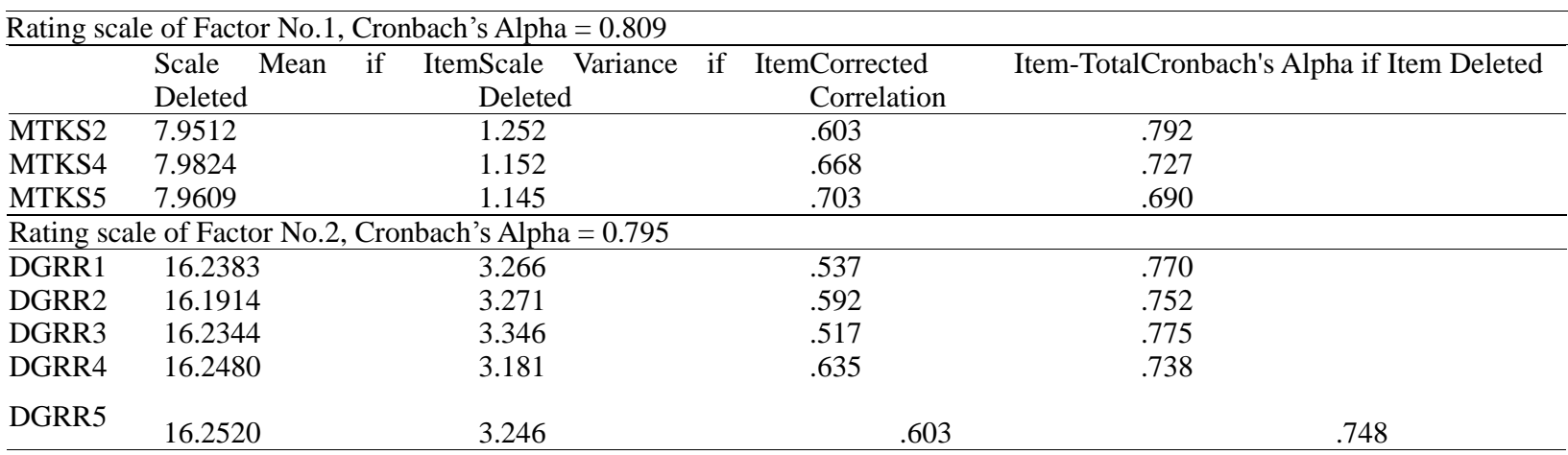

Rating scale of Factor No.3, Cronbach's Alpha $=0.782$

\begin{tabular}{|c|c|c|c|c|c|}
\hline & \multicolumn{2}{|c|}{ Scale Mean if Item DeletedScale } & Variance & ItemCorrected & \multirow[t]{2}{*}{ Item-TotalCronbach's Alpha if Item Deleted } \\
\hline & & Deletec & & Correlation & \\
\hline$\overline{\text { HDKS1 }}$ & 12.0469 & 2.534 & & .577 & .734 \\
\hline HDKS2 & 12.0234 & 2.477 & & .588 & .729 \\
\hline HDKS4 & 12.0234 & 2.583 & & .607 & .720 \\
\hline HDKS5 & 11.9766 & 2.626 & & .579 & .733 \\
\hline
\end{tabular}

Rating scale of Factor No.4, Cronbach's Alpha $=0.727$

\begin{tabular}{llccc}
\hline & Scale Mean if Item Deleted Scale Variance & if & ItemCorrected \\
Deleted & 2.626 & Correlation & Item-TotalCronbach's Alpha if Item Deleted \\
\hline TTTT1 & 11.8535 & 2.735 & .498 & .678 \\
TTTT3 & 11.8496 & 2.543 & .517 & .667 \\
TTTT5 & 11.9648 & 2.576 & .567 & .637 \\
TTTT6 & 11.9277 & .489 & .684 \\
\hline
\end{tabular}

Rating scale of Factor No.5, Cronbach's Alpha $=0.742$

\begin{tabular}{|c|c|c|c|c|}
\hline & Scale Mean if Item Deleted & $\begin{array}{l}\text { Scale } \\
\text { Deleted }\end{array}$ & $\begin{array}{r}\text { Variance if } \begin{array}{r}\text { ItemCorrected } \\
\text { Correlation }\end{array} \\
\end{array}$ & Item-TotalCronbach's Alpha if Item Deleted \\
\hline GS1 & 8.0879 & 1.051 & .535 & .699 \\
\hline GS3 & 8.0078 & 1.115 & .559 & 669 \\
\hline GS4 & 7.9277 & 1.014 & .613 & .603 \\
\hline
\end{tabular}

Rating scale of Factor No.6, Cronbach's Alpha $=0.797$

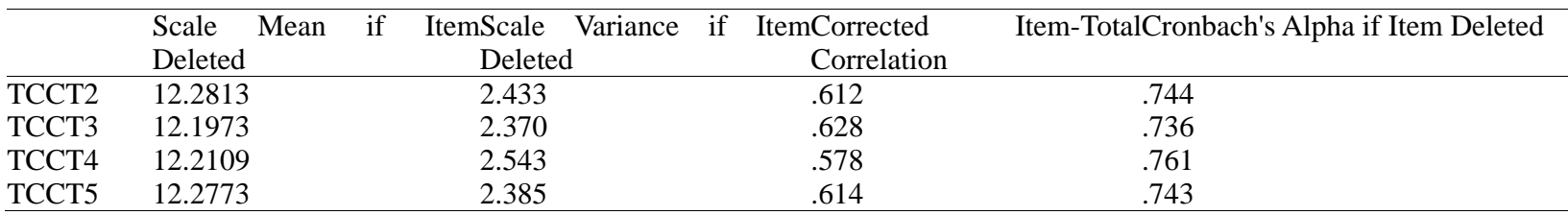

Rating scale of Factor No.7, Cronbach's Alpha $=0.703$

\begin{tabular}{lllll}
\hline LIN1 & 7.8535 & 14.431 & .472 & .648 \\
LIN2 & 7.7813 & 14.246 & .476 & .646 \\
LIN3 & 7.5391 & 13.118 & .541 & .604 \\
LIN4 & 7.9395 & 14.828 & .461 & .655 \\
\hline
\end{tabular}


Rating scale measuring the effectiveness of internal control systems in commercial banks in Vietnam, Cronbach's Alpha = 0.834

\begin{tabular}{lllll}
\hline SHH1 & 8.1719 & 1.125 & .691 & .774 \\
SHH2 & 8.1465 & 1.123 & .675 & .791 \\
SHH3 & 8.1270 & 1.133 & .720 & .747 \\
\hline
\end{tabular}

As can be seen in the test result of the rating scale measuring the effectiveness of internal control systems in commercial banks in Vietnam, the Cronbach's Alpha $=0.834(>0.6)$, the gross correlation coefificients are approximately or greater than 0.5 (much more than the acceptable level of 0.3 ); hence, the reliability of this rating scale is acceptable. After the Cronbach's Alpha test, we used the result acquired from the summary of 512 eligible answers and input variables into EFA to take out factors. The result of the selection of Varimax rotation and shortened down to the variable load factor less than 0:55 after the second time running, the results showed: $\mathrm{KMO}=0.844$ with Sig $=0.000$ significance level and extracting 7 factors with the gross s variance extracted $=60.944 \%$.

Table 2. Result of the second exploratory factor analysis with varimax rotation (KMO and Bartlett's test). Source: The results of analysis from SPSS 20.0 software.

\begin{tabular}{|c|c|c|}
\hline \multicolumn{2}{|l|}{ Kaiser-Meyer-Olkin Measure of Sampling Adequacy. } & .844 \\
\hline & Approx. Chi-Square & 4810.042 \\
\hline Bartlett's Test of Sphericity & df & 351 \\
\hline & Sig. & .000 \\
\hline
\end{tabular}

Table 3. Analysis of the gross variance extracted elements. Source: The results of analysis from SPSS 20.0 software.

\begin{tabular}{|c|c|c|c|c|c|c|c|c|c|}
\hline \multirow[t]{2}{*}{ Component } & \multicolumn{3}{|c|}{ Initial Eigenvalues } & \multicolumn{3}{|c|}{ Extraction Sums of Squared Loadings } & \multicolumn{3}{|c|}{ Rotation Sums of Squared Loadings } \\
\hline & Total & $\begin{array}{l}\% \text { of } \\
\text { Variance }\end{array}$ & $\begin{array}{l}\text { Cumulative } \\
\%\end{array}$ & Total & $\begin{array}{l}\% \text { of } \\
\text { Variance }\end{array}$ & $\begin{array}{l}\text { Cumulative } \\
\%\end{array}$ & Total & $\begin{array}{l}\% \\
\text { Variance }\end{array}$ & ofCumulative \% \\
\hline 1 & 6.806 & 25.209 & 25.209 & 6.806 & 25.209 & 25.209 & 2.711 & 10.039 & 10.039 \\
\hline 2 & 2.188 & 8.103 & 33.312 & 2.188 & 8.103 & 33.312 & 2.534 & 9.384 & 19.423 \\
\hline 3 & 1.917 & 7.101 & 40.412 & 1.917 & 7.101 & 40.412 & 2.423 & 8.974 & 28.397 \\
\hline 4 & 1.636 & 6.058 & 46.471 & 1.636 & 6.058 & 46.471 & 2.307 & 8.544 & 36.941 \\
\hline 5 & 1.477 & 5.469 & 51.940 & 1.477 & 5.469 & 51.940 & 2.290 & 8.483 & 45.424 \\
\hline 6 & 1.260 & 4.665 & 56.605 & 1.260 & 4.665 & 56.605 & 2.156 & 7.984 & 53.408 \\
\hline 7 & 1.171 & 4.339 & 60.944 & 1.171 & 4.339 & 60.944 & 2.035 & 7.536 & 60.944 \\
\hline 8 & .999 & 3.702 & 64.646 & & & & & & \\
\hline 9 & .844 & 3.127 & 67.772 & & & & & & \\
\hline 10 & .799 & 2.958 & 70.730 & & & & & & \\
\hline 11 & .716 & 2.650 & 73.381 & & & & & & \\
\hline 12 & .668 & 2.475 & 75.856 & & & & & & \\
\hline 13 & .634 & 2.349 & 78.204 & & & & & & \\
\hline 14 & .597 & 2.212 & 80.416 & & & & & & \\
\hline 15 & .566 & 2.096 & 82.512 & & & & & & \\
\hline 16 & .532 & 1.970 & 84.482 & & & & & & \\
\hline 17 & .509 & 1.887 & 86.369 & & & & & & \\
\hline 18 & .476 & 1.764 & 88.133 & & & & & & \\
\hline 19 & .451 & 1.672 & 89.805 & & & & & & \\
\hline 20 & .429 & 1.588 & 91.393 & & & & & & \\
\hline 21 & .412 & 1.527 & 92.920 & & & & & & \\
\hline 22 & .393 & 1.456 & 94.376 & & & & & & \\
\hline 23 & .366 & 1.356 & 95.732 & & & & & & \\
\hline 24 & .326 & 1.208 & 96.940 & & & & & & \\
\hline 25 & .318 & 1.179 & 98.119 & & & & & & \\
\hline 26 & .295 & 1.094 & 99.213 & & & & & & \\
\hline 27 & .212 & .787 & 100.000 & & & & & & \\
\hline
\end{tabular}

Extraction Method: Principal Component Analysis. 
Table 4. Result of rotated component matrix. Source: The results of analysis from SPSS 20.0 software.

\begin{tabular}{|c|c|c|c|c|c|c|c|}
\hline & $\begin{array}{l}\text { Component } \\
1\end{array}$ & 2 & 3 & 4 & 5 & 6 & 7 \\
\hline$\overline{\text { DGRR2 }}$ & .720 & & & & & & \\
\hline DGRR1 & .700 & & & & & & \\
\hline DGRR3 & .673 & & & & & & \\
\hline DGRR4 & .637 & & & & & & \\
\hline DGRR5 & .599 & & & & & & \\
\hline TCCT3 & & .773 & & & & & \\
\hline TCCT4 & & .740 & & & & & \\
\hline TCCT2 & & .738 & & & & & \\
\hline TCCT5 & & .675 & & & & & \\
\hline HDKS4 & & & .733 & & & & \\
\hline HDKS1 & & & .694 & & & & \\
\hline HDKS5 & & & .672 & & & & \\
\hline HDKS2 & & & .667 & & & & \\
\hline TTTT5 & & & & .808 & & & \\
\hline TTTT3 & & & & .725 & & & \\
\hline TTTT6 & & & & .663 & & & \\
\hline TTTT1 & & & & .639 & & & \\
\hline MTKS4 & & & & & .840 & & \\
\hline MTKS5 & & & & & .808 & & \\
\hline MTKS2 & & & & & .734 & & \\
\hline LIN3 & & & & & & .777 & \\
\hline LIN2 & & & & & & .715 & \\
\hline LIN1 & & & & & & .709 & \\
\hline LIN4 & & & & & & .692 & \\
\hline GS1 & & & & & & & .789 \\
\hline GS4 & & & & & & & .788 \\
\hline GS3 & & & & & & & .773 \\
\hline Extractio & od: Principal & onent & & & & & \\
\hline Rotation & : Varimax wi & & & & & & \\
\hline
\end{tabular}

As can be seen, 7 factors with the gross variance extracted equal to 60.944\%, which mean these 7 factors can explain for $60.944 \%$ the effectiveness of internal control systems in commercial banks in Vietnam. The calibration model comprises of 7 factors that have inpact on the effectiveness of internal control systems in commercial banks in Vietnam, namely : factor no.1, which is referred to in our study as "Control environment" (motruongkiemsoat); factor no. 2 called "Risk Assessment" (danhgiaruiro); factor no. 3 called " Information and communication" (thongtintruyenthong); factor no. 4 called " Control Activities" (hoatdongkiemsoat); factor no. 5 called " Monitoring" (giamsat); factor no. 6 called " Political institutions" (thechechinhtri) and the final factor called "Group interests" (loiichnhom).

After successfully developing the model of factors that affect the effectiveness of internal control systems in commercial banks in Vietnam, we processed to assess this model by Multiple Regression Analysis (MRA) model to test its appropriateness and to examine the extent to which these factors influence the effectiveness of internal control systems. The result of MRA analysis generated by SPSS with "Enter" method is as follows:

Table 5. Result of assessing the calibrated model (model summary ${ }^{\mathrm{b}}$ ). Source: The results of analysis from SPSS 20.0 software.

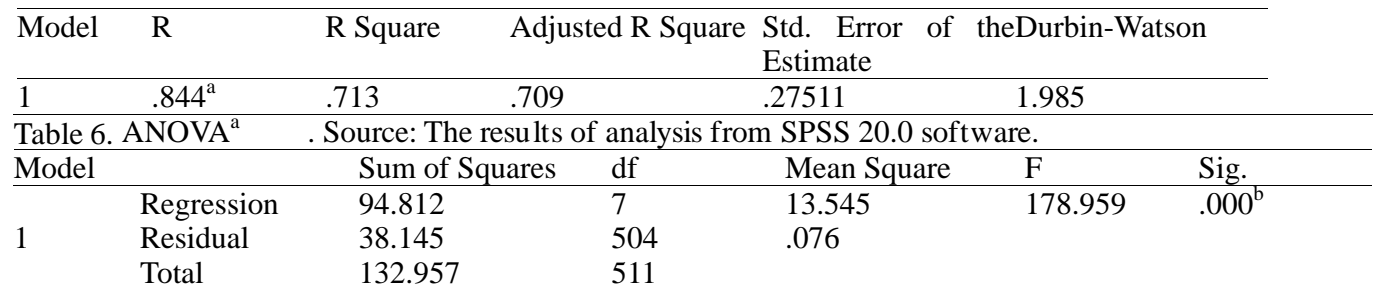

Table 7. Result of MRA with individual regression coefficients in the model. Source: The results of analysis from SPSS 20.0 software.

\begin{tabular}{|c|c|c|c|c|c|c|c|c|}
\hline \multirow{2}{*}{\multicolumn{2}{|c|}{ Model }} & \multicolumn{2}{|c|}{ Unstandardized Coefficients } & \multirow{2}{*}{$\begin{array}{l}\text { Standardized } \\
\text { Coefficients } \\
\text { Beta }\end{array}$} & \multirow[t]{2}{*}{$\mathrm{t}$} & \multirow[t]{2}{*}{ Sig. } & \multicolumn{2}{|c|}{$\begin{array}{l}\text { Collinearity } \\
\text { Statistics }\end{array}$} \\
\hline & & B & Std. Error & & & & Tolerance & VIF \\
\hline \multirow{8}{*}{1} & (Constant) & -.684 & .151 & & -4.516 & .000 & & \\
\hline & Moitruongkiemsoat & .088 & .028 & .090 & 3.193 & .001 & .718 & 1.392 \\
\hline & danhgiaruiro & .377 & .036 & .326 & 10.565 & .000 & .598 & 1.672 \\
\hline & hoatdongkiemsoat & .322 & .031 & .325 & 10.370 & .000 & .579 & 1.728 \\
\hline & Thongtintruyenthong & .154 & .027 & .156 & 5.813 & .000 & .788 & 1.270 \\
\hline & Giamsat & .120 & .027 & .114 & 4.381 & .000 & .847 & 1.180 \\
\hline & thechechinhtri & .145 & .029 & .143 & 4.963 & .000 & .684 & 1.461 \\
\hline & loiichnhom & -.038 & .010 & -.090 & -3.748 & .000 & .987 & 1.013 \\
\hline
\end{tabular}

MRA result shows that adjusted R2 $=0.709$, F-test (ANOVA table) expresses the significance level sig. $=0.000 ;$ thus, 
the regression model is suitable and these factors can explain $70.9 \%$ of the variations of the dependent variable. Considering the regression weights, we can identify the positive correlation between these factors and the effectiveness of internal control systems, these variables are statistically significant due to do sig. $=.000$ ), there is no sign of multicollinearity, or to be specific, these variables are not inter-correlated.

Based on Beta coeffiecient, we can arrange the order affects the effectiveness of internal control systems of these factors in turn were: Risk Assessment (factor no.2), Control Activities (factor no.4), Information and communication (factor no. 3). Political institutions (factor no.6), Monitoring (factor no.5); Control environment (factor no.1), Group interests (factor no7). Thus the model factors affecting the effectiveness of internal control systems in comercial banks in Vietnam remaining 7 factors with specific equation is:

The effectiveness of internal control $=-0.684+0.088$ (Control environment $)+0.377$ (Risk Assessment $)+0.322$ (Control Activities) +0.154 (Information and communication) +0.120 (Monitoring) +0.145 (Political institutions) -0.038 (Group interests).

\section{Testing of hypotheses}

Table 8. Regression analysis results. Source: The results of analysis from SPSS 20.0 software

\begin{tabular}{lllll}
\hline & Result & $\mathrm{b}$ & $\mathrm{T}$ & $\mathrm{p}$ - value \\
\hline H1:MTKS -->SHH & Accept & 0,090 & 3,193 & 0,001 \\
H2: DGRR -->SHH & Accept & 0,326 & 10,565 & 0,000 \\
H3: HDKS -->SHH & Accept & 0,325 & 10,370 & 0,000 \\
H4: TTTT-->SHH & Accept & 0.156 & 5.813 & 0.000 \\
H5: GS --> SHH & Accept & 0,114 & 4,381 & 0,000 \\
H6: TCCT-->SHH & Accept & 0,143 & 4,963 & 0,000 \\
H7: LIN--> SHH & Accept & -0.090 & $-3,748$ & 0,000 \\
\hline
\end{tabular}

Compared with previous researches, this research discovered two factors that affect the effectiveness of the internal control system in the commercial bank of Vietnam: political institutions and interest groups.

\section{Conclusion}

This is an empirical study on the pattern of factors affecting the effectiveness of internal control systems in comercial banks in Vietnam in recent years. Based on the results of research, we came up with the key factors that affect the effectiveness of internal control systems were: Control environment; Risk Assessment; Control Activities; Information and communication; Monitoring; Political institutions; Group interests. Detection is very important to advice given reasonable solutions thereby improving the effectiveness of internal control systems in comercial banks in Vietnam in the coming time.

\section{Limitations of this Study}

In this research, author mainly based on the constituent factors of internal control system in accordance with COSO and BASEL organizations and have added two factors consistent with conditions in Vietnam are: political institutions and interest groups. The next research can investigate other factors, especially the factors within the commercial bank of Vietnam. In addition, the scope of the research is not to mention the foreign bank. Therefore, further researches need to expand the scope of research to many other objects.

\section{References}

Allan J. C., \& Burdett, A. L. (1995). Interest Group Politics, Congressional Quarterly Press, 89.

Angella, A., \& Eno, L. I. (2009). Evaluation of Internal Control Systems: A Case Study from Uganda, International Research Journal of Finance and Economics, 27(2009), 125-144. Retrieved from https://www.researchgate.net/publication/282736409_Evaluation_of_Internal_Control_Systems_A_Case_Study_fr om_Uganda

Basel committee of Supervision. (1998). Framework for internal control systems in Banking organization.

Beck, T., A. Demirguc-Kunt, \& R. Levine. (2003). Law, Endownment and Finance, Journal of Financial Economics, 70, 137-181. http://dx.doi.org/10.1016/S0304-405X(03)00144-2

Calomiris, C. W., \& Kahn, C. M. (1991). The Role of demandable debt in structuring optimal bank arrangements, American economic Review, 81(3), 497-513. Retrieved from http://links.jstor.org/sici?sici=0002-8282\%28199106\%2981\%3A3\%3C497\%3ATRODDI\%3E2.0.CO\%3B2-E\&ori gin=repec

Canadian Institute of Chartered Accountants (CICA)-Criteria of Control.(1994). CoCo-An Overview. CICA. Retrie ved 
from http://www.cica.ca.

Committee of Sponsoring Organisations of the Treadway Commission (COSO). (1992). Internal control-integrated framework. New York, NY: AICPA.

Committee of Sponsoring Organisations of the Treadway Commission (COSO). (2013). The 2013 Internal ControlIntegrated Framework. New York, NY: AICPA

D'Aquila, J. M. (1998). Is the control environment related to financial reporting decisions? Hagan School of Business, New York. NY.

Diamond, D. W. (1984). Financial Intermediation and delegated monitoring, Review of economic Studies LTD, 393-414. http://www.jstor.org/stable/2297430

Doyle, J., Ge, W., \& McVay, S. (2007). Determinants of weaknesses in internal control over financial reporting. Journal of Accounting and Economics, 44, 193-223. http://dx.doi.org/10.1016/j.jacceco.2006.10.003

Frank, S. (1977). Social Problems. Dreyden Press USA, p.632.

Ge, W., \& McVay, S. (2005). The disclosure of material weaknesses in internal control after the Sarbanes-Oxley Act. Accounting Horizons, 19(3), 137-158. http://dx.doi.org/10.2308/acch.2005.19.3.137.

Hevesi, G. (2005). Internal Control Standards in New York States Government. Retrieved from http://www.osc.ny.us/audit/control/standards.htm2009june6.

Jenkinson, N. (2008). Strengthening Regimes for Controlling Liquidity Risks: Some Lessons from the Recent Turmoil. London: the Euromoney Conference on Liquidity and Funding Risk Management. Retrieved from http://www.bis.org/review/r080425f.pdf

Kaufmann, D., Kraay, A., \& Mastruzzi, M. (2009). Governance matters VIII: Aggregate and individual governance indicators 1996-2008, World bank policy research, working paper 4280.

Kenjegalieva, A., \& Simper, R. (2011). Aproductivity analysic of Central and Eastern European banking taking into acount risk decomposition and environmental variables, Research in International Business and Finance, 25(1), 26-38. http://dx.doi.org/10.1016/j.ribaf.2010.05.003

Kopp, L. S., \& O’Donnell, Ed. (2005). The Influence of a Business-process Focus on Category Knowledge and Internal Control Evaluation. Accounting, Organizations and Society, 30, 423-434. http://dx.doi.org/10.1016/j.aos.2004.03.004

Lannoye, M. A. (1999). Evaluation of internal Controls. Retrieved from http://www.michighan.gov/documents/gf_master1_26775_7.pdf.

Muhota, K. (2005). Check list for an internal Audit.Giving Hope to World of Need. USA.

Ofori, W. (2011). Effectiveness of Internal Control System: A perception or Reality, Retrieved from http://ir.knust.edu.gh/bitstream/123456789/4435/1/WILLIAM\%20OFORI\%20FINAL\%20THESIS\%202011.pdf.

Rae, K., \& Subramaniam, N. (2008). Quality of Internal Control Procedures: Antecedents and Moderating Effect on Organizational Justice and Employee Fraud. Managerial Auditing Journal, 23(2), 104-124. http://dx.doi.org/10.1108/02686900810839820

Ramos, M. (2004). Evaluate the Control Environment: Documentation Is Only a Start; Now it's All about Asking Questions. Journal of Accounting, 197, 75-78. Retrieved from http://saskatoonlibrary.ca/eds/item?dbid=edsgis\&an=edsgcl.118443317

Rawls, J. A. (1971). Theory of justice, N.Y: 60.

Robert, M. B. \& Abbie, J. S. (2003). Transparency, Financial Accounting Information and Corporate Governance: New York Economic Policy Review, 9(1), 65-87. Retrie ved from http://ssrn.com/abstract=795547

Spinger, L. M. (2004). Management's Responsibility for Internal Control. Retrieved from http://www.whitehouse.gov/omb/index.html.

Steihoff. (2001). Internal Control Management and Evaluation Tool. United States General Accounting Office. Retrieved from http://www.gao.gov/assets/80/76615.pdf

Sultana, R., \& Haque, M. E. (2011). Evaluation of Internal Control Structure: Evidence from Six Listed Banks in Bangladesh, ASA University Review, 5(1), 69-81. Retrieved from http://www.asaub.edu.bd/data/asaubreview/v5n1s14.pdf

Turnbull Committee. (1999). Internal control: Guidance for directors on the combined code. ICAEW, London: 
Working Party of the Committee on Corporate Governance.

Walker, D. M. (1999). Standards for Internal Control in Federal Government. Retrieved from http://www.gao.gov/special.pubs/ai00021p.pdf

Zingales's. (1998). Corporate Governance. The New Palgrave Dictionary of Economics and the Law, 1-20. http://dx.doi.org/10.2139/ssrn.46906

\section{Copyrights}

Copyright for this article is retained by the author(s), with first publication rights granted to the journal.

This is an open-access article distributed under the terms and conditions of the Creative Commons Attribution license (http://creativecommons.org/licenses/by/3.0/). 